\title{
Applicator Dosing Unit
}

National Cancer Institute

\section{Source}

National Cancer Institute. Applicator Dosing Unit. NCI Thesaurus. Code C62412.

A dosing unit equal to the amount of active ing redient(s) contained in a single applicator. 